\title{
Comparison of a GE Lunar DPX-IQ and a Norland XR-26 dual energy X-ray absorptiometry scanner for body composition measurements in pigs - in vivo
}

\author{
DOROTHEA LÖSEL ${ }^{1}$, PRISCA KREMER ${ }^{2}$, ELKE ALBRECHT ${ }^{1}$ and ARMIN M. SCHOLZ ${ }^{2}$
}

${ }^{1}$ Leibniz Insitute for Farm Animal Biology, Dummerstorf, Germany, ${ }^{2}$ Livestock Center, University Munich, Munich, Germany

\begin{abstract}
In the context of future growth and performance testing, this study compares corresponding body composition results measured by two dual energy X-ray absorptiometry systems. To test the capability of each device to detect differences among experimental groups widely varying in body composition, 77 pigs from 6 purebred/crossbred groups were used for the experiment. Each pig was scanned consecutively on a Norland XR-26 and on a GE Lunar DPX-IQ. Coefficients of determination were: $R^{2}=0.92$ for bone mineral content (BMC), $R^{2}=0.90$ for bone mineral density (BMD), $R^{2}=0.94$ for lean mass (LEAN), $R^{2}=0.92$ for fat mass (FAT), $R^{2}=0.88$ for lean percentage (\%LEAN) and fat percentage (\%FAT). However, Norland yielded larger values for \%FAT and smaller values for \%LEAN, BMC, and BMD than Lunar $(P<0.001)$ with the extent of deviation depending on the specific trait and on the breeding group. The deviation in BMC was greater than the deviation in BMD, suggesting different bone detecting algorithms. Both systems revealed similar differences among the breeding groups, and ranked them in the same order based on numerical values. Differences in calibration, bone detection, and software algorithms, however, require a prior crosscalibration to make the body composition data from both systems directly comparable. Finally, they can be used across research centres for the determination of relative and absolute body composition differences among animal groups and individuals.
\end{abstract}

Keywords: pig, body composition, cross-calibration, dual energy X-ray absorptiometry, in vivo

\section{Zusammenfassung}

\section{Vergleich eines GE Lunar DPX-IQ und eines Norland XR-26 \\ Dualenergie-Röntgenabsorptiometrie-Gerätes zur Messung der Körperzusammensetzung von Schweinen in vivo}

Im Hinblick auf zukünftige Wachstums- und Leistungsprüfungen vergleicht diese Studie parallele Messergebnisse der Körperzusammensetzung von lebenden Schweinen, die mit zwei Dualenergie-Röntgenabsorptiometrie-Gerätesystemen ermittelt wurden. Um zu überprüfen, ob beide Geräte geeignet sind, Unterschiede zwischen Versuchsgruppen mit stark variierenden Körperzusammensetzungen zu erkennen, wurden 77 Schweine aus 6 Reinzucht/Kreuzungszucht-Gruppen verwendet. Jedes Schwein wurde nacheinander auf 
einem Norland XR-26 und einem GE Lunar DPX-IQ gemessen. Die Bestimmheitsmaße betrugen: $R^{2}=0.92$ für Knochenmineralgehalt $(B M C), R^{2}=0.90$ für Knochenmineraldichte (BMD), $R^{2}=0.94$ für Magermasse (LEAN), $R^{2}=0.92$ für Fettmasse (FAT), $R^{2}=0.88$ für Mageranteil (\%LEAN) und Fettanteil (\%FAT). Allerdings lieferte Norland größere Werte für \%FAT und kleinere Werte für \%LEAN, BMC und BMD als Lunar $(P<0.001)$, wobei das Ausmaß der Abweichung von dem jeweiligen Merkmal und der Kreuzungsgruppe abhing. Die Abweichung bei BMC war größer als bei BMD, was unterschiedliche Algorithmen zur Knochendetektion vermuten lässt. Norland und Lunar ermittelten ähnliche Unterschiede zwischen den Kreuzungsgruppen bei gleicher Rangfolge basierend auf numerischen Werten. Um Unterschiede bei Kalibrierung, Knochendetektion und Software-Algorithmen auszugleichen sowie zur direkten Vergleichbarkeit der Ergebnisse der beiden Geräte, ist eine vorangehende Kreuzkalibrierung notwendig. In der Folge können beide Systeme institutionsübergreifend eingesetzt werden, um relative bzw. absolute Unterschiede der Körperzusammensetzung zwischen Tiergruppen und Individuen zu bestimmen.

Schlüsselwörter: Schwein, Körperzusammensetzung, Kreuzkalibrierung, DualenergieRöntgenabsorptiometrie, in vivo

\section{Introduction}

Determination of body composition using dual energy X-ray absorptiometry (DXA) is increasingly used in animal science with a large number of publications involving mainly swine (MITCHELL et al. 1996a, 1996b, 2002, MITCHELL and SCHOLZ 1997, 2009, DUNSHEA et al. 2003, SUSTER et al. 2003, BEE et al. 2007), chicken (MITCHELL et al. 1997, BUYSE et al. 2003, SWENNEN et al. 2004), turkey (SCHÖLLHORN and SCHOLZ 2007, KREUZER 2008), sheep (CLARK et al. 1999), and calves (BASCOM et al. 2002, SCHOLZ et al. 2003, HAMPE et al. 2005). The technology quantifies fat, lean tissue, bone mineral content (BMC), and bone mineral density (BMD) very reliably. The most important advantage of DXA compared with the traditional techniques of dissection and chemical analysis is that it is non-invasive which allows multiple measurements on the same animal over lifetime. However, it is known from phantom and partly human volunteer studies that DXA bone mineral and body composition results may vary among instruments from different manufacturers and even between software versions of the same manufacturer depending on different software and hardware settings (TOTHILL et al. 1994a, 1994b, DIESSEL et al. 2000). Therefore, results from animal studies that were conducted at different experimental units using different DXA devices are not exactly comparable without prior cross-calibration (SCHOLZ et al. 2007). Cross-calibrations can be performed with body composition phantoms that consist of various liquid and solid materials (TOTHILL et al. 1999, VOZAROVA et al. 2001, HAMMAMI et al. 2002, RUGE 2007). However, in vivo cross-calibrations are more accurate than phantom- based cross-calibrations (DIESSEL et al. 2000).

The aim of this study was - for the first time - to directly compare the body composition measurements of a GE Lunar DPX-IQ and a Norland XR-26 using live pigs. With respect to multi-centre growth or performance testing, both DXA devices were evaluated for their capability of detecting differences among groups of pigs. 


\section{Material and methods}

\section{Animals}

The experiment was conducted at the Livestock Center Oberschleissheim of the LudwigMaximilians-University Munich (LVG) in accordance with the protocol approved by the government of Upper Bavaria with the tracking number 55.2-1-54-2531.2-60-07. A total of 77 pigs (7 boars, 33 barrows, 37 gilts) originating from different extensive or conventional breeds or crossbreds was used for the experiment. Animals were assigned to 6 purebred/crossbred groups (breeding groups) depending on their genetic background: Cerdo lberico (lb; $n=5 ; 45-55$ kg, age $161 \mathrm{~d}$ ); Duroc (Du) $\times$ lb (Dulb; $n=15 ; 67-101$ kg; 159-162 d); German Landrace + German Large White = White Sow Lines (WSL; $\mathrm{n}=8$; 52-79 kg; 140-167 d); Hampshire (Ha) + Pietrain (Pi) $\times$ Ha + Pi $\times$ PiHa (Pi_Ha; n=6; 54-88 kg; 126$189 \mathrm{~d}) ; \mathrm{Pi} \times \mathrm{Du}+\mathrm{Pi} \times \mathrm{PiDu}$ (Pi_Du; $\mathrm{n}=24 ; 42-102$ kg; 123-172 d); and Pi $\times$ WSL + PiDu $\times$ WSL (Pi_WSL; $n=19 ; 42-94$ kg; 122-173 d). The breeding groups served primarily as an example for experimental animal batches with variable body composition. It was not our main intention to characterize the breeding groups according to their body composition. After a $16 \mathrm{~h}$ fasting period, pigs were sedated with an intramuscular injection of $1.2 \mathrm{mg} / \mathrm{kg}$ body weight of azaperone (Stresnil, Janssen-Cilag GmbH, Neuss, Germany) and $40 \mathrm{mg} / \mathrm{kg}$ body weight of ketamine hydrochloride (Ursotamin 10\%, Serumwerk Bernburg AG, Bernburg, Germany). Subsequently, an intravenous catheter was inserted into an ear vein enabling a follow-up dosing of Ursotamin - if necessary. After the scan procedure, the pigs were moved into a separate pen to enable a gentle recovery phase from anesthesia.

\section{Body composition measurements}

Each pig was scanned consecutively on two DXA devices. The GE Lunar DPX-IQ (Lunar; software version 4.7e, GE Healthcare, Chalfont St. Giles, United Kingdom) is located at the Livestock Center Oberschleissheim (LVG). The Norland XR-26 (Norland; computer software version 2.5.3a, Norland Corporation, White Plains, NY, USA) is usually located at the Leibniz Institute for Farm Animal Biology Dummerstorf (FBN) and had been transported to the LVG to enable a cross-calibration between the two devices using the same animals alive. Accuracy and precision of both devices for body composition measurements on pigs in vivo and post mortem based on reference data from carcass dissection (and chemical analysis) were published earlier (Norland: LÖSEL et al. 2007, Lunar: SCHOLZ et al. 2002, SCHOLZ and FÖRSTER 2006, SCHOLZ et al. 2007) and therefore were not investigated in the present study.

On both devices, animals were placed on the DXA tables in a prone position with the hind legs extended and slightly tied together while the front legs were positioned along the side but kept away from the body by two wedges of foam plastic. The two single scan procedures were operated using either the »whole body« (Norland) or whole body »adult normal« (Lunar) modes.

The Norland software provides predetermined regions on the scan image for the calculation of the composition of different parts of the body. However, as described earlier (LÖSEL et al. 2007) we used the results of an additionally defined region that covered the whole body. The values displayed for this new region were: BMD, BMC, lean 
mass (LEAN), and fat mass (FAT). The total tissue mass (TTM) was calculated by summing BMC, LEAN, and FAT. Lean percentage (\%LEAN) and fat percentage (\%FAT) were calculated by dividing LEAN and FAT by TTM, respectively.

The Lunar software provides values for BMD, BMC, soft tissue mass, FAT, \%FAT, and LEAN. The TTM was calculated by summing soft tissue mass and BMC. Lean percentage (i.e. \%LEAN) was calculated by dividing LEAN by TTM.

\section{Statistical evaluation}

Statistical analysis was performed using the SAS statistical software (Version 9.2, SAS Inst. Inc., Cary, NC, USA).

Linear single regression analysis was used to determine the relationship between values for TTM, LEAN, FAT, BMC, BMD, \%LEAN, and \%FAT derived by the two DXA devices. The results of the regression analysis are given as coefficient of determination $\left(R^{2}\right)$, standard error of estimation (SEE = root mean square error), intercept ( \pm SE) and slope $( \pm S E)$. The value from Norland was considered as the response variable (y) and the value from Lunar as explanatory variable $(\mathrm{x})$.

Effects of DXA device and breeding group on measures of composition were analyzed using a mixed model procedure with device, sex and device $\times$ breeding group interaction as fixed effects. Animal was considered as a random effect. Because of the unbalanced sex distribution (small number of intact males, inconsistent frequency of sexes across breeding groups), no breeding group $\times$ sex interaction was considered. Age was used as covariate. Values are given as least squares means \pm standard errors of the differences of means (SED). Differences between breeding groups were analyzed by Tukey's test option within the mixed model procedure.

\section{Results}

\section{Differences between devices}

As shown in Table 1, there existed a high agreement between Norland and Lunar for the measurement of body composition in pigs in vivo $\left(R^{2}=0.88\right.$ to 1$)$. The coefficients of determination were greater for tissue masses than for tissue percentages. Though, when taking into account the total of 77 pigs, significant differences in each body composition trait were observed between the two DXA devices $(P<0.001$; Table 2$)$. The deviation was less than $4 \%$ for TTM, LEAN, and \%LEAN and 18 to $20 \%$ for BMC, FAT, and \%FAT. Norland yielded larger values for TTM, FAT, and \%FAT and smaller values for all other traits.

Even when considering each breeding group separately, differences between the two DXA devices were still apparent for most traits. Norland yielded smaller BMD values than Lunar in all breeding groups $(P<0.001$; Table 3$)$. The deviation was smallest in Dulb (less than $6 \%$ ) and about 10 to $12 \%$ in the other breeding groups. The smaller BMD was associated with smaller BMC values (Table 3 ) in all breeding groups $(P<0.001)$ except $\mathrm{lb}$ $(P=0.20)$. However, compared with BMD, the deviation for BMC was greater (9 to $22 \%)$. The Norland device measured greater TTM values (Table 4) in each breeding group $(P<0.05)$, although the deviation was very small $(0.5 \%$ in Pi_WSL to $2.5 \%$ in Dulb). 
Table 1

Relationship between GE Lunar DPX-IQ (explanatory variable $=\mathrm{x}$ ) and Norland XR-26 (response variable $=\mathrm{y}$ ) DXA devices for whole body composition measurements in pigs in vivo (with $y=a+b x ; a=i n t e r c e p t, b=s l o p e$ )

Beziehung zwischen den GE Lunar DPX-IQ (erklärende Variable $=x$ ) und Norland XR-26 (Zielvariable $=y$ ) DXA-Geräten für Messungen der Ganzkörperzusammensetzung von Schweinen in vivo mit $y=a+b x ; a=A c h s e n a b s c h n i t t, b=S t e i g u n g$

\begin{tabular}{lcccc}
\hline Trait & $\mathrm{R}^{2}$ (adjusted) & SEE & Intercept (SE) & Slope (SE) \\
\hline Total tissue mass, $\mathrm{kg}$ & 1.00 & 0.73 & $-1.036(0.419)$ & $1.03(0.01)$ \\
Bone mineral density, $\mathrm{g} / \mathrm{cm}^{2}$ & 0.90 & 0.04 & $-0.46(0.05)$ & $1.34(0.05)$ \\
Bone mineral content, g & 0.92 & 105 & $328.61(46.23)$ & $0.64(0.02)$ \\
Lean mass, kg & 0.94 & 2.33 & $-0.06(1.56)$ & $0.98(0.03)$ \\
Fat mass, kg & 0.92 & 2.34 & $-0.35(0.59)$ & $1.23(0.04)$ \\
Lean percentage, \% & 0.88 & 3.06 & $-13.81(3.79)$ & $1.14(0.05)$ \\
Fat percentage, \% & 0.88 & 3.01 & $0.42(0.91)$ & $1.16(0.05)$ \\
\hline
\end{tabular}

All coefficients of determination $\left(R^{2}\right)$ were statistically significant $(P<0.001)$.

Table 2

Body composition traits determined with the Norland XR-26 and the GE Lunar DPX-IQ DXA device ( $n=77$; least squares means and standard errors of differences)

Merkmale der Körperzusammensetzung, bestimmt mittels Norland XR-26 und GE Lunar DPX-IQ

\begin{tabular}{lcccc}
\hline Trait & GE Lunar DPX-IQ & Norland XR-26 & SED & $P$ \\
\hline Total tissue mass, kg & 67.45 & 68.37 & 0.09 & $<0.001$ \\
Bone mineral density, g/cm & 1.05 & 0.94 & 0.007 & $<0.001$ \\
Bone mineral content, g & 2024 & 1659 & 28 & $<0.001$ \\
Lean mass, kg & 52.34 & 51.00 & 0.30 & $<0.001$ \\
Fat mass, kg & 13.05 & 15.70 & 0.33 & $<0.001$ \\
Lean percentage, $\%$ & 78.27 & 75.19 & 0.39 & $<0.001$ \\
Fat percentage, $\%$ & 18.74 & 22.34 & 0.39 & $<0.001$ \\
\hline
\end{tabular}

Table 3

Bone mineral density and bone mineral content of 6 breeding groups determined with the GE Lunar DPX-IQ and the Norland XR-26 DXA device (least squares means and standard errors of differences)

Knochenmineraldichte $\left(\mathrm{g} / \mathrm{cm}^{2}\right)$ und Knochenmineralgehalt $(\mathrm{g})$ in 6 Kreuzungsgruppen, bestimmt mittels $G E$ Lunar DPX-IQ und Norland XR-26

\begin{tabular}{lcccc}
\hline Breeding group & GE Lunar DPX-IQ & Norland XR-26 & SED & $P$ \\
\hline Bone mineral density, g/cm & & & & \\
Ib & $1.01^{\mathrm{a}}$ & $0.88^{\mathrm{a}}$ & 0.02 & $<0.001$ \\
Dulb & $1.14^{\mathrm{b}}$ & $1.08^{\mathrm{b}}$ & 0.01 & $<0.001$ \\
WSL $^{1}$ & $1.07^{\mathrm{ab}}$ & $0.96^{\mathrm{a}}$ & 0.02 & $<0.001$ \\
Pi_Ha & $1.02^{\mathrm{a}}$ & $0.89^{\mathrm{a}}$ & 0.02 & $<0.001$ \\
Pi_Du & $1.04^{\mathrm{a}}$ & $0.93^{\mathrm{a}}$ & 0.01 & $<0.001$ \\
Pi_WSL & $0.99^{\mathrm{a}}$ & $0.87^{\mathrm{a}}$ & 0.02 & $<0.001$ \\
Bone mineral content, g & & & & \\
lb & $1352^{\mathrm{a}}$ & $1231^{\mathrm{a}}$ & 93 & 0.196 \\
Dulb & $2515^{\mathrm{c}}$ & $1974^{\mathrm{b}}$ & 53 & $<0.001$ \\
WSL & $2209^{\mathrm{bc}}$ & $1841^{\mathrm{bc}}$ & 73 & $<0.001$ \\
Pi_Ha & $1896^{\mathrm{b}}$ & $1562^{\mathrm{ab}}$ & 85 & $<0.001$ \\
Pi_Du & $2149^{\mathrm{b}}$ & $1763^{\mathrm{bc}}$ & 42 & $<0.001$ \\
Pi_WSL & $2023^{\mathrm{b}}$ & $1582^{\mathrm{ac}}$ & 47 & $<0.001$ \\
\hline
\end{tabular}

Ib Cerdo Iberico $(n=5)$, Dulb Duroc $\times$ Ib $(n=15)$, WSL White Sow Lines, German Landrace + German Large White $(\mathrm{n}=8)$, Pi_Ha Hampshire $(\mathrm{Ha})+$ Pietrain $(\mathrm{Pi}) \times \mathrm{Ha}+\mathrm{Pi} \times \mathrm{PiHa}(\mathrm{n}=6), \quad \mathrm{Pi} \_\mathrm{Du} \mathrm{Pi} \times \mathrm{Du}+\mathrm{Pi} \times \mathrm{PiDu}(\mathrm{n}=24), \mathrm{Pi}$ WSL Pi $\times$ WSL + PiDu $\times$ WSL $(n=19)$. a,b,c Means within a column with different superscripts differ $(P<0.05)$. ' ${ }^{1}$ WSL Vs. Pi_WSL: $P=0.09$ for both Lunar and Norland. ${ }^{2} \mathrm{Dulb}$ vs. $\mathrm{Pi}$ Ha: $P=0.09$ for Norland. Device $\times$ breeding group interaction: $P<0.001$. 
Table 4

Total tissue mass, lean mass, lean percentage, fat mass, and fat percentage of 6 breeding groups determined with the GE Lunar DPX-IQ and the Norland XR-26 DXA device (least squares means and standard errors of differences)

Gesamtgewebemasse, Magermasse, Mageranteil, Fettmasse und Fettanteil in 6 Kreuzungsgruppen, bestimmt mittels GE Lunar DPX-IQ und Norland XR-26

\begin{tabular}{|c|c|c|c|c|}
\hline Breeding group1 & GE Lunar DPX-IQ & Norland XR-26 & SED & $P$ \\
\hline \multicolumn{5}{|c|}{ Total tissue mass, $\mathrm{kg}$} \\
\hline $\mathrm{lb}$ & $46.62^{\mathrm{a}}$ & $47.40^{\mathrm{a}}$ & 0.30 & 0.011 \\
\hline Dulb & $74.00^{\mathrm{b}}$ & $75.83^{b}$ & 0.17 & $<0.001$ \\
\hline WSL & $72.34^{b}$ & $73.30^{\mathrm{b}}$ & 0.24 & $<0.001$ \\
\hline Pi_Ha & $66.34^{\mathrm{b}}$ & $67.21^{\mathrm{b}}$ & 0.28 & 0.003 \\
\hline Pi_Du & $74.14^{b}$ & $74.82^{b}$ & 0.14 & $<0.001$ \\
\hline Pi_WSL & $71.28^{b}$ & $71.64^{b}$ & 0.16 & 0.023 \\
\hline \multicolumn{5}{|l|}{ Lean mass, kg } \\
\hline $\mathrm{lb}$ & $32.00^{\mathrm{a}}$ & $30.20^{\mathrm{a}}$ & 0.99 & 0.075 \\
\hline Dulb & $52.64^{b}$ & $49.91^{b}$ & 0.58 & $<0.001$ \\
\hline WSL & $57.48^{\mathrm{bc}}$ & $56.18^{\mathrm{bc}}$ & 0.79 & 0.104 \\
\hline Pi_Ha & $55.19^{\mathrm{bc}}$ & $54.07^{\mathrm{bc}}$ & 0.91 & 0.220 \\
\hline Pi_Du & $60.09^{c}$ & $59.79^{c}$ & 0.46 & 0.501 \\
\hline Pi_WSL & $56.83^{b c}$ & $55.86^{c}$ & 0.51 & 0.062 \\
\hline \multicolumn{5}{|c|}{ Lean percentage, $\%$} \\
\hline $\mathrm{lb}$ & $69.92^{\mathrm{a}}$ & $65.19^{\mathrm{a}}$ & 1.30 & $<0.001$ \\
\hline Dulb & $72.03^{\mathrm{a}}$ & $66.98^{\mathrm{a}}$ & 0.75 & $<0.001$ \\
\hline WSL & $80.20^{\mathrm{b}}$ & $77.16^{\mathrm{b}}$ & 1.03 & 0.004 \\
\hline Pi_Ha & $83.95^{\mathrm{b}}$ & $81.22^{\mathrm{b}}$ & 1.19 & 0.025 \\
\hline Pi_Du & $81.81^{\mathrm{b}}$ & $80.74^{b}$ & 0.60 & 0.076 \\
\hline Pi_WSL & $81.71^{b}$ & $79.85^{b}$ & 0.67 & 0.007 \\
\hline \multicolumn{5}{|l|}{ Fat mass, kg } \\
\hline $\mathrm{lb}$ & $13.26^{\mathrm{ab}}$ & $15.97^{\mathrm{a}}$ & 1.10 & 0.016 \\
\hline Dulb & $18.84^{\mathrm{b}}$ & $23.94^{b}$ & 0.64 & $<0.001$ \\
\hline WSL & $12.65^{\mathrm{ab}}$ & $15.28^{\mathrm{a}}$ & 0.87 & 0.004 \\
\hline Pi_Ha & $9.25^{\mathrm{a}}$ & $11.58^{\mathrm{a}}$ & 0.10 & 0.024 \\
\hline Pi_Du & $11.90^{\mathrm{a}}$ & $13.27^{\mathrm{a}}$ & 0.50 & 0.008 \\
\hline Pi_WSL & $12.42^{\mathrm{a}}$ & $14.19^{\mathrm{a}}$ & 0.57 & 0.003 \\
\hline \multicolumn{5}{|l|}{ Fat percentage, $\%$} \\
\hline $\mathrm{lb}$ & $27.18^{\mathrm{a}}$ & $32.22^{\mathrm{a}}$ & 1.28 & $<0.001$ \\
\hline Dulb & $24.59^{\mathrm{a}}$ & $30.42^{\mathrm{a}}$ & 0.74 & $<0.001$ \\
\hline WSL & $16.71^{\mathrm{b}}$ & $20.33^{b}$ & 1.01 & $<0.001$ \\
\hline $\mathrm{Pi} \_\mathrm{Ha}$ & $13.19^{b}$ & $16.47^{\mathrm{b}}$ & 1.17 & 0.007 \\
\hline Pi_Du & $15.28^{b}$ & $16.90^{\mathrm{b}}$ & 0.59 & 0.007 \\
\hline Pi_WSL & $15.49^{b}$ & $17.94^{b}$ & 0.66 & $<0.001$ \\
\hline
\end{tabular}

Ib Cerdo Iberico $(n=5)$, Dulb Duroc $\times \mathrm{lb}(\mathrm{n}=15)$, WSL White Sow Lines, German Landrace + German Large White $(n=8)$, Pi_Ha Hampshire $(\mathrm{Ha})+$ Pietrain $(\mathrm{Pi}) \times \mathrm{Ha}+\mathrm{Pi} \times \mathrm{PiHa}(\mathrm{n}=6), \quad \mathrm{Pi} \_\mathrm{Du} \mathrm{Pi} \times \mathrm{Du}+\mathrm{Pi} \times \mathrm{PiDu}(\mathrm{n}=24), \quad \mathrm{Pi}$ WSL Pi $\times$ WSL + PiDu $\times$ WSL $(n=19)$. $\quad{ }^{a}, b, c$ Means within a column with different superscripts differ within trait $(P<0.05)$. Device $\times$ breeding group interaction: $P<0.001$.

For LEAN (Table 4), the difference between Norland and Lunar was very small throughout all breeding groups. In Dulb, the LEAN determined by Norland was by $5.2 \%$ smaller compared with Lunar $(P<0.001)$. In Ib, WSL, and Pi_WSL the LEAN values tended to be smaller when obtained by Norland compared with Lunar $(P=0.075,0.104$, and 0.062 , 
respectively), but the two devices did not yield different results in Pi_Ha and Pi_Du ( $P=0.22$ and 0.50 , respectively). Consequently, also \%LEAN (Table 4) from Norland was significantly smaller for all breeding groups, with the exception of Pi_Du $(P=0.076)$. A large deviation occurred also for FAT. Norland measured a considerably larger FAT than Lunar (Table 4) in all breeding groups. The deviation ranged from $12 \%$ in Pi_Du $(P=0.008)$ to $27 \%$ in Dulb $(P<0.001)$. Correspondingly, the resulting\%FAT was larger for Norland compared with Lunar $(P<0.01$; Table 4). Again, the smallest deviation was found in Pi_Du (value by $11 \%$ smaller compared with Lunar, $P=0.007$ ), but the largest difference was observed in Pi_Ha $(25 \%, P=0.007)$.

\section{Differences among breeding groups}

Despite the absolute differences in measured values, both DXA scanners detected differences in body composition among the breeding groups (within device) similarly. The ranking of breeding groups was identical for all traits except TTM. Both Norland and Lunar detected the greatest BMD in Dulb differing significantly from all other breeding groups $(P<0.01)$, except that Lunar did not find a significant difference between Dulb and WSL $(P=0.44)$. In both devices (Table 3$)$, the breeding group with the second greatest BMD (WSL) tended to differ $(P=0.09)$ from the group with the smallest BMD (Pi_WSL).

The Dulb pigs had the numerically largest BMC (Table 3 ) in both devices. However, the differences among breeding groups were more pronounced for Lunar than for Norland, e.g. Pi_WSL had a 1.5 -fold $(P<0.001)$ and 1.3 -fold $(P=0.34)$ greater value than $\mathrm{lb}$ when obtained by Lunar or Norland, respectively. The TTM (Table 4) was almost identical in Dulb and Pi_Du when measured by Lunar (difference $0.14 \mathrm{~kg}$ ), whereas Norland - although not statistically significant - yielded a one kilogram greater value in Dulb compared with Pi_Du.

Pi_Du yielded the greatest LEAN mass followed by WSL outperforming lb significantly by more than $25 \mathrm{~kg}$ LEAN in both devices (Table 4). According to Norland, Dulb and Pi_WSL differed in LEAN $(P=0.041)$, however, Lunar-derived LEAN did not differ significantly between these breeding groups $(P=0.40)$. The Pi_Ha displayed the largest value for\%LEAN, and Ib pigs displayed the smallest\%LEAN (Table 4). In both devices, Ib and Dulb did not differ significantly, but showed a considerably smaller\%LEAN than the other 4 breeding groups $(P<0.01)$. The largest amount of FAT was found in Dulb, which differed significantly from all other breeding groups within the Norland measurements $(P<0.05$; Table 4). Generally, the FAT mass differences among the breeding groups are slightly larger within Norland than within Lunar measurements. For example, the numerically fattest breeding group, Dulb, showed a 1.5 -fold greater value than the second fattest group, $\mathrm{lb}$, with Norland $(P=0.036)$, but only a 1.4-fold greater value with Lunar $(P=0.389)$. The ranking for\%FAT (Table 4) was Pi_Ha $<$ Pi_Du $<$ Pi_WSL $<$ WSL $<$ Dulb $<\mathrm{lb}$. As expected from the\%LEAN value, Pi_Ha showed the numerically lowest \%FAT and was not different from the other 3 lean breeding groups WSL, Pi_Du, Pi_WSL. The fat breeding groups $\mathrm{lb}$ and Dulb differed significantly from all other breeding groups within both devices $(P=0.01)$. 


\section{Discussion}

Dual-energy X-ray absorptiometry is an approved method for the determination of body composition in pigs. Fields of application include feeding trials, evaluation of growth modifiers, genetic selection, and evaluation of housing conditions (MITCHELL and SCHOLZ 1997, 2008, MITCHELL et al. 1998c, DUNSHEA et al. 2003, PURSEL et al. 2004, MARCOUX et al. 2005, SUSTER et al. 2006). However, it is still not possible to directly compare the DXA body composition results among different DXA devices (TOTHILL et al. 1994b, 1999, KISTORP and SVENDSEN 1997, LANTZ et al. 1999; Plank 2005). Thus, for comparison of data from future multi-center studies, it was imperative to determine the agreement of results generated from the GE Lunar DPX-IQ and the Norland XR-26 devices.

In vivo cross-calibration using 77 pigs from a wide range of body compositions demonstrated good linear agreement with coefficients of determination greater than 0.88 between the two devices. However, a high coefficient of determination does not exclude systematic differences. In fact, highly significant differences in absolute values between Lunar and Norland measurements were reported for all traits considering the total of 77 pigs and for most of the traits when looking at the individual breeding groups. This was not a surprising finding, because comparisons among Lunar, Hologic, or Norland devices using phantoms or human volunteers showed that the values for body composition or bone parameters were highly correlated with each other, but significantly different (GENANT et al. 1994, TOTHILL et al. 1994a, 1994b, PIERSON et al. 1995). In vivo cross-calibrations between pencil-beam and fan-beam devices of the same manufacturer also showed significant differences among the absolute measured values (Hologic: KOO et al. 2003, GE Lunar: CRABTREE et al. 2005). Even the analysis of the same scan with different software versions (KOO et al. 2004) and - most notable - identical devices with identical software (LANTZ et al. 1999) yielded different results.

It has to be stated here that it was not the aim of the present study to determine which DXA device predicted body composition of pigs more accurately. It is well known that correction equations are needed to adjust the raw DXA output to pigs (MITCHEL et al. 1996a, 1996b, MITCHELL et al. 1998a, 1998b, SUSTER et al. 2003). However, some of the factors that affect accuracy also contribute to differences between different devices. There are several reasons for those differences which arise from the basic principle of the DXA technology.

With two X-ray energies, only two tissue components can be determined in each pixel. In pixels with soft tissue only, the scanning software distinguishes between fat and nonfat (lean) tissue. In the presence of bone, it distinguishes between bone and soft tissue. The proportions of fat and lean overlying and underlying bone must be extrapolated from neighbouring pixels that contain only soft tissue (ROUBENOFF et al. 1993, PIETROBELLI et al. 1996, 1998). Devices differ in their hardware components such as methods for X-ray generation, detectors, and scan acquisition technique (fan beam vs. pencil beam). Both devices in the present study are pencil beam scanners, but employ different K-edge filters (cerium vs. samarium) which yield different energy peaks (38 and $70 \mathrm{keV}$ vs. 46.8 and $80 \mathrm{keV}$ ). It is unlikely that different energy levels per se account for inter-device differences. More important, Norland scanners feature a dynamic filtration system that optimizes the photon count rate for varying tissue thickness by automatically 
selecting the proper samarium filter combination. In fact, a significant effect of tissue thickness on accuracy has been demonstrated for Lunar and Hologic scanners using physical models (LASKEY et al. 1992, JEBB et al. 1995). In vivo, this impact has not been confirmed as reported by LUKASKI et al. (1999) who compared whole body scans of pigs lying in the prone or side position and reported no significant effect of body thickness in the range of $16-28 \mathrm{~cm}$ on accuracy. It is not clear to what extent Norlands dynamic filtration systems affects the comparability with Lunar, because GOTFREDSEN et al. (1997) using a Norland XR-36 still found a small but significant impact of tissue thickness on $\%$ FAT and BMC, and even the Operator's Guide for the XR-26 notes that inaccuracies and imprecision may occur at tissue heights above $20 \mathrm{~cm}$.

The biggest part of inter-device differences probably arises from the way the software processes the obtained raw data. This includes differences in software algorithms (e.g. bone detection, assumptions regarding distribution of soft tissue above or below bone) and the calibration procedure that relates the measured $R$ value to a certain component. The $R$ values of the body components (pure fat, bone, and bone free soft tissue) are known from theoretical calculations and in vitro measurements, but manufacturers use different calibration standards. For bone mineral calibration Norland and Hologic use hydroxyapatite alone, whereas Lunar takes into account that bone contains also fat (TOTHILL 1995). Lunar devices appear to measure systematically higher values for BMC and BMD than Norland and Hologic devices (LASKEY et al. 1991, MAZESS et al. 1991, TOTHILL et al. 1994a, CAWTE et al. 1999). This was also demonstrated in the present study where Lunar yielded significantly larger BMD and BMC values. The areal BMD is calculated by dividing the measured BMC by the bone area, which is determined from the number of bone containing pixels (TOTHILL 1995). The deviation between Lunar and Norland was greater for BMC than for BMD suggesting that the devices not only differ in measuring the BMC in a given pixel, but also in their ability to detect bone containing pixels. The Norland output does not give a value for bone area, but this can be calculated from BMC and BMD. It appears that Norland measured a smaller total bone area (data not shown) in all breeding groups with the exception of Ib (Lunar: $1339 \mathrm{~cm}^{2}$; Norland: $1399 \mathrm{~cm}^{2}$ ), which was also the only breeding group where no significant difference in BMC was observed. However, the resulting BMD was significantly smaller when measured by Norland. The largest differences in bone detection occurred in Dulb as indicated by the largest deviation in BMC, but the smallest deviation in BMD. Differences in the measurement of bone area are caused by the capability of a device to accurately detect the bone edge, including differences in the threshold value for bone detection. CAWTE et al. (1999), comparing Lunar and Hologic devices, reported higher BMD values from Lunar and assumed that the edge detection algorithm of the Lunar device eliminated more low density bone than the Hologic device resulting in a smaller area and a consequently higher BMD. Comparing a fan beam with a pencil beam DXA device (Lunar), CRABTREE et al. (2005) found a smaller bone area to be associated with a lower BMC in the fan beam device, but the resulting BMD was not different. We do not know whether the GE Lunar DPX-IQ utilizes a lower bone detection threshold than the Norland XR-26, but in the present study Lunar yielded a larger bone area. 
Probably, the resolution of the scan mode had a greater impact than the bone detection algorithm on delineation of bone. Norland used a larger pixel size $(6.5 \times 13 \mathrm{~mm})$ than Lunar $(4.8 \times 9.6 \mathrm{~mm})$. Pixels that include a small amount of bone may be counted as lean tissue, because their average $R$ value is closer to that of lean tissue than to bone. This error increases with increasing pixel size (ROUBENOFF et al. 1993). In vivo cross-calibration studies yielded inconsistent results. KOO et al. (2004) and CRABTREE et al. (2005) reported that an underestimation of BMD or BMC was associated with an overestimation of LEAN and an underestimation of FAT. However, other studies (KISTORP and SVENDSEN 1997; LANTZ et al. 1999) found opposite effects (overestimation of FAT and underestimation of LEAN) which is in accordance with the Norland results in the present study. Different assumptions about fat distribution may cover the effect of bone threshold and pixel size in the present study. The fat distribution models, which are not revealed in detail by manufacturers, are relevant for the estimation of soft tissue composition in bone containing pixels and thus would contribute to differences in whole body composition. Norland's fat distribution model for the whole body measurement assumes that fat is concentrated in the outer layers of the body and the proportion of lean is greater near the bone. For estimation of soft tissue composition in bone pixels, they use a weighted linear distribution model, with the pixels nearer the bone weighted more heavily in the regression (NORD and PAYNE 1995). This model is more valid in the limbs than in the trunk, because in the limbs the amount and composition of the soft tissue can be assumed to be similar behind and in front of bone. In contrast, adipose tissue in the trunk is not uniformly distributed which makes soft tissue composition in the trunk more difficult to estimate. TOTHILL et al. (1994b) found the greatest deviation between Norland, Lunar, and Hologic scanners in the trunk region, which demonstrates the general difficulty of estimating soft tissue composition in the trunk and the different assumptions about fat distribution. In addition, differences in bone detection contribute to the problems in the trunk region because they are expected to have a larger impact on bone mineral results and soft tissue composition in body regions of low BMD such as the rib cage. Therefore, it is likely that different algorithms are used for the estimation of tissue composition in different body regions, which makes the definition of regions of interest (ROI) particularly important. Whereas the Lunar scanner defines the regions of interest automatically, the Norland XR-26 scanner requires the manual definition of ROI before data analysis which is a potential source of error. With the Norland scanner in the present study, whole body composition was analyzed in an additionally defined region covering the whole body because the results yielded by this approach showed a closer relationship to nominal body composition derived by chemical analysis and dissection than the results from the pre-defined ROI (LÖSEL et al. 2007). However, the assumptions and algorithms in this new region are not known.

The extent of deviation between the two devices varied according to the specific trait; the differences for BMC, FAT, and \%FAT were much greater than for the other traits. Regarding the absolute tissue masses, the higher FAT obtained by Norland became apparent at the expense of LEAN and BMC. In addition, the larger TTM seemed to be completely identified as fat. The largest deviation in TTM was found in Dulb, which was 
numerically the heaviest breeding group according to Norland, but only the second heaviest breeding group after Pi_Du according to Lunar.

When comparing TTM of Dulb and Pi_Du, the nominal difference was $0.14 \mathrm{~kg}$ according to Lunar, but $1 \mathrm{~kg}$ according to Norland. Dulb also had the greatest nominal inter-device difference in LEAN and the greatest relative difference in \%LEAN. However, the relative differences in FAT and \%FAT were in a similar range as in Pi_Ha, a breeding group with a lower body weight and significantly smaller \%FAT than Dulb suggesting that the extent of deviation does not depend on the \%FAT alone. On the other hand, although the body weight was similar to Dulb, the smallest deviation in soft tissue composition traits were observed in Pi_Du suggesting that the extent of deviation does not depend on body weight alone.

We chose an in vivo approach rather than the use of a phantom for the crosscalibration between the Lunar DPX-IQ and the Norland XR-26 for two reasons. First, the use of phantoms may underestimate deviations between different scanners. According to DIESSEL et al. (2000) the main limitations of phantoms are that they are not anthropomorphic in terms of weight and size and contain only a simplified skeleton. As outlined above, bone influences the determination of soft tissue composition. The differences between devices regarding bone detection and estimation of soft tissue composition above and below the bone, which is a challenge particularly in the trunk, become more evident in vivo. Second, we could test the ability of the two devices to detect differences between groups of pigs (here: breeding groups) which is the main purpose of DXA analyses in our experimental stations. Altogether, Norland and Lunar ranked the breeding groups in the same order based on numerical values. Significantly different results of the two devices regarding the discrimination between breeding groups occurred predominantly when in one breeding group the extent of inter-device deviation was smaller or greater than in the other breeding groups, which often involves the fat groups Dulb or Ib. For example, the deviation in BMC between Lunar and Norland was smaller in $\mathrm{lb}$ than in the other breeding groups, and the difference between Dulb and Pi_WSL was significant according to Lunar, but not significant according to Norland. However, differences in the most interesting trait for growth and performance testing, i.e. $\% F A T$, were demonstrated by both devices in the same way.

In conclusion, the data from Norland XR-26 and the GE Lunar DPX-IQ DXA scanners are not directly comparable without cross-calibration because Norland yielded smaller BMC, $B M D$, and lean values, but greater fat values. The extent of the deviation between scanners depended on the trait and on the breeding group. In most cases, both devices measured differences among breeding groups consistently, and therefore can be used across research centres for the determination of relative and absolute body composition differences among animal groups and individuals. Direct comparison of absolute values for body composition or bone mineralization traits, however, requires the use of regression equations. 


\section{References}

Bascom SS, Huffard CS, Nickols-Richardson SM, Hovingh EP, James RE, McGillard ML (2002) Analysis of body composition of Jersey bull calves fed varying levels of fat and protein with dual energy X-ray absorptiometry. J Anim Sci 80(Suppl.1), 336 (Abstr.)

Bee G, Pursel VG, Mitchell AD, Maruyama K, Wells KD, Solomon MB, Wall RJ, Coleman ME, Schwartz RJ (2007) Carcass composition and skeletal muscle morphology of swine expressing an insulin-like growth factor I transgene. Arch Tierz 50, 501-19

Buyse J, Swennen Q, Janssens GPJ, Decuypere E, Geers R (2003) Evaluation of dual-energy X-ray absorptiometry to determine the in vivo body composition of broilers. In: Souffrant WB, Metges CC (Eds) Progress in research on energy and protein metabolism. EAAP publication, vol. 109. Wageningen Academic Publishers, Wageningen, 477-80

Cawte SA, Pearson D, Green DJ, Maslanka WB, Miller CG, Rogers AT (1999) Cross-calibration, precision and patient dose measurements in preparation for clinical trials using dual energy X-ray absorptiometry of the lumbar spine. Br J Radiol 72, 354-62

Clarke RD, Kirton AH, Bartle CM, Dobbie PM (1999) Application of dual-energy x-ray absorptiometry for ovine carcass evaluation. Proc New Zeal Soc Anim Prod 59, 272-4

Crabtree NJ, Shaw NJ, Boivin CM, Oldroyd B, Truscott JG (2005) Pediatric in vivo cross-calibration between the GE Lunar Prodigy and DPX-L bone densitometers. Osteoporosis Int 16, 2157-2167

Diessel E, Fuerst T, Njeh CF, Tylavsky F, Cauley J, Dockrell M, Genant HK (2000) Evaluation of a new body composition phantom for quality control and cross-calibration of DXA devices. J Appl Physiol 89, 599-605

Dunshea FR, Suster D, Kerton DJ, Leury BJ (2003) Exogenous porcine somatotropin administered to neonatal pigs at high doses can alter lifetime fat but not lean tissue deposition. Br J Nutr 89, 795-801

Genant HK, Grampp S, Glüer CC, Faulkner KG, Jergas M, Engelke K, Hagiwara S, van Kuijk C (1994) Universal standardization for dual $\mathrm{x}$-ray absorptiometry: patient and phantom cross-calibration results. J Bone Miner Res 9, 1503-14

Gotfredsen A, Bæksgaard L, Hilsted J (1997) Body composition analysis by DEXA by using dynamically changing samarium filtration. J Appl Physiol 82, 1200-9

Hampe J, Nüske S, Scholz AM, Förster M (2005) In vivo analysis of body composition and growth of calves of different genetic origin using dual energy x-ray absorptiometry (DXA). Arch Tierz 48, 428-44 [in German]

Hammami M, Picaud JC, Fusch C, Hockman EM, Rigo J, Koo WW (2002) Phantoms for cross-calibration of dual energy X-ray absorptiometry measurements in infants. J Am Coll Nutr 21, 328-32

Jebb SA, Goldberg GR, Jennings G, Elia M (1995) Dual-energy X-ray absorptiometry measurements of body composition: effects of depth and tissue thickness, including comparisons with direct analysis. Clin Sci 88, 319-24

Kistorp CN, Svendsen OL (1997) Body composition analysis by dual energy X-ray absorptiometry in female diabetics differ between manufacturers. Eur J Clin Nutr 51, 449-54

Koo WW, Hammami M, Hockman EM (2003) Interchangeability of pencil-beam and fan-beam dualenergy X-ray absorptiometry measurements in piglets and infants. Am J Clin Nutr 78, 236-40

Koo WW, Hammami M, Shypailo RJ, Ellis KJ (2004) Bone and body composition measurements of small subjects: discrepancies from software for fan-beam dual energy X-ray absorptiometry. J Am Coll Nutr 23, 647-50

Kreuzer B (2008) Effect of different energy levels in »ecological« turkey fattening diets on the growth pattern of one turkey genotype, measured by dual energy X-ray absorptiometry (DXA). PhD Dissertation Ludwig-Maximilians-University Munich, Germany [in German]

Lantz H, Samuelson G, Bratteby LE, Mallmin H, Sjöström L (1999) Differences in whole body measurements by DXA-scanning using two Lunar DPX-L machines. Int J Obes 23, 764-70

Laskey MA, Flaxman ME, Barber RW, Trafford S, Hayball MP, Lyttle KD, Crisp AJ, Compston JE (1991) Comparative performance in vitro and in vivo of Lunar DPX and Hologic QDR-1000 dual energy X-ray absorptiometers. Br J Radiol 64, 1023-9

Laskey MA, Lyttle KD, Flaxman ME, Barber RW (1992) The influence of tissue depth and composition on the performance of the Lunar dual energy X-ray absorptiometer whole-body scanning mode. Eur J Clin Nutr 46, 39-45

Lösel D, Küchenmeister U, Hartung M, Nürnberg G, Bellmann O, Albrecht E (2007) Non-invasive determination of body composition in pigs using a Norland XR-26 bone densitometer. Arch Tierz 50, 487-500 
Lukaski HC, Marchello MJ, Hall CB, Schafer DM, Siders WA (1999) Soft tissue composition of pigs measured with dual X-ray absorptiometry: comparison with chemical analyses and effects of carcass thicknesses. Nutrition 15, 697-703

Marcoux M, Faucitano L, Pomar C (2005) The accuracy of predicting carcass composition of three different pig genetic lines by dual-energy X-ray absorptiometry. Meat Sci 70, 655-63

Mazess RB, Trempe JA, Bisek JP, Hanson JA, Hans D (1991) Calibration of dual-energy x-ray absorptiometry for bone density. J Bone Miner Res 6, 799-806

Mitchell AD, Scholz AM (1997) Dual-energy x-ray absorptiometry (DXA) analysis of growth and body composition of pigs of different ryanodine receptor genotypes. Arch Tierz 40, 11-21

Mitchell AD, Scholz AM (2008) Efficiency of energy and protein deposition in swine measured by dual energy X-ray absorptiometry (DXA). Arch Tierz 51, 160-72

Mitchell AD, Scholz AM (2009) Relationships among dual-energy X-ray absorptiometry, bioelectrical impedance and ultrasound measurements of body composition of swine. Arch Tierz 52, 28-39

Mitchell AD, Conway JM, Potts WJ (1996a) Body composition analysis of pigs by dual-energy X-ray absorptiometry. J Anim Sci 74, 2663-71

Mitchell AD, Conway JM, Scholz AM (1996b) Incremental changes in total and regional body composition of growing pigs measured by dual-energy X-ray absorptiometry. Growth Dev Aging 60, 95-105

Mitchell AD, Scholz AM, Conway JM (1998a) Body composition analysis of small pigs by dual-energy Xray absorptiometry. J Anim Sci 76, 2392-8

Mitchell AD, Scholz AM, Conway JM (1998b) Body composition analysis of pigs from 5 to $97 \mathrm{~kg}$ by dual energy X-ray absorptiometry. Appl Radiat Isot 49, 521-3

Mitchell AD, Scholz AM, Pursel VG (2002) Prediction of the in vivo body composition of pigs based on cross-sectional region analysis of dual energy X-ray absorptiometry (DXA) scans. Arch Tierz 45, 535-45

Mitchell AD, Scholz AM, Pursel VG, Evock-Clover CM (1998c) Composition analysis of pork carcasses by dual-energy X-ray absorptiometry. J Anim Sci 76, 2104-14

Mitchell AD, Rosebrough RW, Conway JM (1997) Body composition analysis of chickens by dual energy x-ray absorptiometry. Poult Sci 76, 1746-52

Nord RH, Payne RK (1994) Body composition by dual-energy X-ray absorptiometry: a review of the technology. Asia Pac J Clin Nutr 4, 167-71

Pierson RNJr., Wang J, Thornton JC, Kotler DP, Heymsfield SB, Weber DA, Ma RM (1995) Bone mineral and body fat measurements by two absorptiometry systems: comparisons with neutron activation analysis. Calcif Tissue Int 56, 93-8

Pietrobelli A, Formica C, Wang Z, Heymsfield SB (1996) Dual-energy X-ray absorptiometry body composition model: review of physical concepts. Am J Physiol 271 (Endocrinol. Metab. 34), E941-E951

Pietrobelli A, Wang Z, Formica C, Heymsfield SB (1998) Dual-energy X-ray absorptiometry: fat estimation errors due to variation in soft tissue hydration. Am J Physiol 274 (Endocrinol. Metab. 37), E808-E816

Plank LD (2005) Dual-energy X-ray absorptiometry and body composition. Curr Opin Clin Nutr Metab Care 8, 305-9

Pursel VG, Mitchell AD, Bee G, Elsasser TH, McMurtry JP, Wall RJ, Coleman ME, Schwartz RJ (2004) Growth and tissue accretion rates of swine expressing an insulin-like growth factor I transgene. Anim Biotechnol 15, 33-45

Roubenoff R, Kehayias JJ, Dawson-Hughes B, Heymsfield SB (1993) Use of dual-energy X-ray absorptiometry in body-composition studies: not yet a "gold standard". Am J Clin Nutr 58, 589-91

Ruge A (2006) Evaluation of the accuracy of a Norland XR26 DXA system in comparison with a GE Lunar DPX-IQ applying a modified variable composition phantom. PhD Dissertation Ludwig-MaximiliansUniversity, Munich, Germany [in German]

Schöllhorn B, Scholz AM (2007) Study on the suitability of dual energy x-ray absorptiometry (DXA) for whole body composition measurements in two turkey genotypes. Arch Geflügelk 71, 228-36

Scholz AM, Förster M (2006) Accuracy of dual energy x-ray absorptiometry (DXA) for the determination of the body composition of pigs in vivo. Arch Tierz 49, 462-76 [in German]

Scholz A, Soffner P, Littmann E, Peschke W, Förster M (2002) Accuracy of dual energy x-ray absorptiometry (DXA) measurements for the determination of the composition of carcass halfs (cold, 30$39 \mathrm{~kg}$ ) from swine in comparison to the EU reference dissection. Züchtungsk 74, 376-391 [in German]

Scholz AM, Nüske S, Förster M (2003) Body composition and bone mineralization in calves of different genetic origin by using dual energy x-ray absorptiometry. Acta Diabetol 40 (Suppl. 1), S91-S94

Scholz AM, Mitchell AD, Förster M, Pursel VG (2007) Two-site evaluation of the relation between in vivo and carcass dual energy $\mathrm{x}$-ray absorptiometry (DXA) in pigs. Livest Sci 110, 1-11 
Suster D, Leury BJ, Kerton DJ, Dunshea FR (2006) Dual energy X-ray absorptiometry predicts the effects of dietary protein on body composition of pigs. Aust J Exp Agric 46, 1439-45

Suster D, Leury BJ, Ostrowska E, Butler KL, Kerton DJ, Wark JD, Dunshea FR (2003) Accuracy of dual energy X-ray absorptiometry (DXA), weight and P2 back fat to predict whole body and carcass composition in pigs within and across experiments. Livest Prod Sci 84, 231-42

Swennen Q, Janssens GP, Geers R, Decuypere E, Buyse J (2004) Validation of dual-energy x-ray absorptiometry for determining in vivo body composition of chickens. Poult Sci 83, 1348-57

Tothill P (1995) Dual-energy X-ray absorptiometry for the measurement of bone and soft tissue composition. Clin Nutr 14, 263-8

Tothill P, Avenell A, Reid DM (1994a) Precision and accuracy of measurements of whole-body bone mineral: comparisons between Hologic, Lunar and Norland dual-energy X-ray absorptiometers. $\mathrm{Br} J$ Radiol. 68, 1210-7

Tothill P, Avenell A, Love J, Reid DM (1994b) Comparisons between Hologic, Lunar and Norland dualenergy X-ray absorptiometers and other techniques used for whole body soft tissue measurements. Eur J Clin Nutr 48, 781-94

Tothill P, Laskey MA, Orphanidou Cl, van Wijk M (1999) Anomalies in dual energy X-ray absorptiometry measurements of total-body bone mineral using Lunar, Hologic and Norland instruments. Brit J Radiol 72, 661-9

Vozarova B, Wang J, Weyer C, Tataranni PA (2001) Comparison of two software versions for assessment of body-composition analysis by DXA. Obes Res $9,229-32$

Received 12 November 2009, accepted 6 January 2010.

Corresponding author:

\section{ELKE ALBRECHT}

email: elke.albrecht@fbn-dummerstorf.de

Leibniz Institute for Farm Animal Biology, Wilhelm-Stahl-Allee 2, 18196 Dummerstorf, Germany 